\title{
Patients' perceptions and attitude towards MRI safety in Asir Region, Saudi Arabia
}

\author{
Magbool Alelyani (iD \\ Moawia Gameraddin (D) ${ }^{2}$ \\ Azah Alasmari (iD) \\ Fay Alshahrani' \\ Nada Alqahtani $\mathbb{D}^{\prime}$ \\ Alamin Musa $\mathbb{D}^{\prime}$ \\ 'Department of Radiological Sciences, \\ College of Applied Medical Sciences, King \\ Khalid University, Abha, 61413, Saudi \\ Arabia; ${ }^{2}$ Department of Diagnostic \\ Radiologic Technology, Faculty of Applied \\ Medical Sciences, Taibah University, \\ Almadinah, Kingdom of Saudi Arabia
}

Correspondence: Moawia Gameraddin Department of Diagnostic Radiologic Technology Faculty of Applied Medical Sciences, Taibah University, Almadinah, Kingdom of Saudi Arabia

Email gameraldinm@gmail.com
Purpose: To assess the knowledge and attitudes of Saudi patients toward the safety of magnetic resonance imaging (MRI).

Methods: A cross-sectional study was conducted on 142 Saudi patients at King Khalid hospital, Asir, Saudi Arabia. Data were collected using a self-questionnaire based on MRI safety issues gained from the literature. The questionnaire was divided into two sections, one containing the respondents' sociodemographic information and the other assessing their knowledge and attitudes toward participating in MRI.

Results: A total of 142 patients responded to the survey, and their average age was $31.5 \pm 4$ years. The majority were married and held a bachelor's degree. The mean knowledge score regarding MRI safety was $0.29 \pm 0.25$, which reflects poor knowledge, whereas the attitude score was $0.67 \pm 0.20$, reflecting a moderately positive attitude. Awareness and attitude among patients improved as education levels increased. Finally, only $53.5 \%$ of the respondents were aware of the noise produced by the MRI scanner.

Conclusion: This study demonstrated that the awareness of MRI safety among patients in the Asir Region is poor, although they showed positive attitudes toward the issue. Thus, education is necessary for patients to improve awareness of MRI safety to facilitate MRI examinations, which will help decrease scan time and image artefacts.

Keywords: perceptions, attitudes, MRI safety, awareness, patients

\section{Introduction}

Magnetic resonance imaging (MRI) is a non-invasive imaging tool that generates 3D images with superior diagnostic, anatomical, and physiological information of the body. ${ }^{1}$ MRI does not use ionizing radiation, as in CT and general radiology, making it a useful tool for follow-up appointments regarding disease without exposing the body to hazardous radiation.

The basic MRI principle relies primarily on the technique that excites and records changes in the direction of the rotational axis of hydrogen nuclei within the water molecules found in all the tissues of the body. ${ }^{1}$ Therefore, MRI is the perfect diagnostic tool for the joints, brain, breast, and other soft tissues of the body due to its high soft tissue contrast resolution compared with that of other imaging methods. This superior resolution gives the opportunity to obtain some angiographic images without the need for contrast enhancement, unlike CT and conventional angiography. ${ }^{2}$

It was reported that patient hazards during such examinations could result from MRI's strong static magnetic field, the time varying dynamic gradient, the radiofrequency field (RF), or the high acoustic noises during MRI scan. ${ }^{3,4}$ To ensure the 
safety of patients and health workers, the "foundational American College of Radiology White Paper on MR Safety" was issued in the year 2002. ${ }^{5}$

The principles of MR Safe Practice Guidelines are intentionally applied to patients as well as diagnostic settings, research subjects, and health care personnel safety and for all MRI settings. ${ }^{6}$ The main concern in MRI is its strong static magnetic field from the highly powered magnet, which was reported to cause serious bioeffects to patients, operators, or the machine. ${ }^{7-9}$ Therefore, a number of considerations must be taken before beginning an MRI scan, and patients should be aware of safety information.

The need for documented guidelines on MR safety practices emerged from a growing awareness of the MR environment's potential risks that involve patients, personnel, and equipment. In previous studies, some patients have reported a twitching sensation during MRI examinations, nerve stimulation, and burns. ${ }^{10,11}$ Additionally, claustrophobia has also been reported. ${ }^{12}$ Patients suffering from claustrophobia will struggle to endure the excessively long scan time within the MRI machine.

Furthermore, a patient's lack of knowledge regarding MRI examination may lead to anxiety or the inability to remain still during the exam, resulting in motion artifact and insufficient image quality. Therefore, the primary concern of this study was patient awareness about MR safety hazards, which is crucial to ensure proper and safe MRI examination, especially with the growing indications for MRI examinations. The ultimate aim of this study was to assess patient perceptions and attitudes toward MRI safety in the Asir Region, Saudi Arabia.

\section{Patients and Methods}

\section{Survey Assessment and Administrating}

This was a descriptive, cross-sectional study conducted to assess the knowledge and attitudes of patients toward MRI safety. Study approval was obtained from the ethical committee of King Khalid University. An electronic questionnaire was designed to contain variables related to knowledge of and attitudes toward MRI safety issues. The survey was generated on Google Surveys and was built as close-ended "Yes/No" answers.

The study was conducted in Asir Central Hospital and Armed Forces Hospital in the Kingdom of Saudi Arabia. Participants were chosen using the convenience sampling method from February to March 2021. They were asked to fill out the electronic questionnaire before starting the MRI examination and were told to answer the questionnaire individually. A total of 142 responses were received.

The study population contained a spectrum of patients with different levels of education, including primary school, middle school, high school, bachelor's degrees, and diplomas. Only four patients had master's degrees. All the participants were divided into five different age groups. The survey contained independent variables, which included sociodemographic characteristics such as gender, marital status, and education level, whereas the dependent variables included questions related to the patient's awareness of and attitudes toward MRI safety.

\section{Data Analyses}

The data were analyzed and interpreted using the statistical software SPSS version 22.0 (IBM Corporation, Armonk, NY). The reliability of the questions was estimated using Cronbach's alpha, which measured 75.6. The frequency and percentage of participants' responses were estimated. Descriptive statistics was used to estimate the means of score knowledge and attitude across gender, age groups, and educational status. A chi-square test was applied to find an association between claustrophobia and gender. The level of significance was set at 0.05 . Finally, the number of correct responses was calculated to assess the mean score of attitude and level of knowledge among the participants.

\section{Results}

The questionnaire was sent to 250 patients, and 142 sheets were returned, a response rate of $56.8 \%$. The evidence of internal consistency for the questions was $75.6 \%$, indicating the reliability of the instrument.

Table 1 shows the socio-demographics of the participants. Of the 142 patients, there were 103 (72.5\%) men and $39(27.5 \%)$ women. Participants of 20-29 years were the most populated group (27.5\%), followed by those aged $40-49$ years $(27.2 \%)$. There were only four patients aged $<20$ years $(2.8 \%)$. In the realm of education level, most of the patients had a bachelor's degree 68 (47.9\%), followed by a diploma, higher secondary school, and primary and middle schools. Lastly, patients with master's degrees were the least common (2.8\%).

With regard to participants' history of claustrophobia (Figure 1), 83.6\% $(\mathrm{n}=56)$ of females has claustrophobia, while $16.4 \%(n=11)$ of males had history of claustrophobia. Therefore, claustrophobia in females was significantly higher than males ( $\mathrm{p}$-value $=0.005$ ). 
Table I Social Characteristics of Participants

\begin{tabular}{|c|c|c|}
\hline Variables & Frequency & Percent \% \\
\hline \multicolumn{3}{|l|}{ Gender } \\
\hline Male & 103 & 72.5 \\
\hline Female & 39 & 27.5 \\
\hline \multicolumn{3}{|l|}{ Age groups } \\
\hline$<20$ years & 4 & 2.8 \\
\hline 20-29 years & 39 & 27.5 \\
\hline $30-39$ years & 33 & 23.2 \\
\hline 40-49 years & 34 & 23.9 \\
\hline 50-59 years & 28 & 19.7 \\
\hline$>60$ years & 4 & 2.8 \\
\hline \multicolumn{3}{|l|}{ Average age $=31 \pm 4$ years } \\
\hline \multicolumn{3}{|l|}{ Marital status } \\
\hline Single & 44 & 31.0 \\
\hline Married & 98 & 69.0 \\
\hline \multicolumn{3}{|l|}{ Level of education } \\
\hline Primary \& middle school & 16 & 11.3 \\
\hline Higher secondary school & 26 & 18.3 \\
\hline Diploma & 28 & 19.7 \\
\hline Bachelor's degree & 68 & 47.9 \\
\hline Master's degree & 4 & 2.8 \\
\hline
\end{tabular}

\section{Knowledge}

The first set of questions (1-11) aimed to assess the MRI knowledge of patients, and Table 2 shows the distribution and percentages of correct and incorrect responses to each question. The awareness of the patients toward preparation, types, differences between ionizing and nonionizing radiations, differences between MRI compatible and incompatible devices, and the adverse reactions of MRI contrast agents were 115 (81), 113 (79.6\%), 126 (88.7), and 121 (85.2\%), respectively (Table 2). Furthermore, the patients showed satisfactory knowledge toward the production of noise from MRI 76 (53.5\%). A total of $114(80.3 \%)$ and $130(91.5 \%)$ of respondents believed incorrectly that pregnant women could be scanned by MRI and given contrast agents, respectively (Table 2). The knowledge score increased in single participants compared to the married ones ( 0.37 vs 0.21$)$, and the score increased in those who had Bachelor's degree than the other ones. The knowledge score showed no difference among age groups and gender as shown in Table 3.

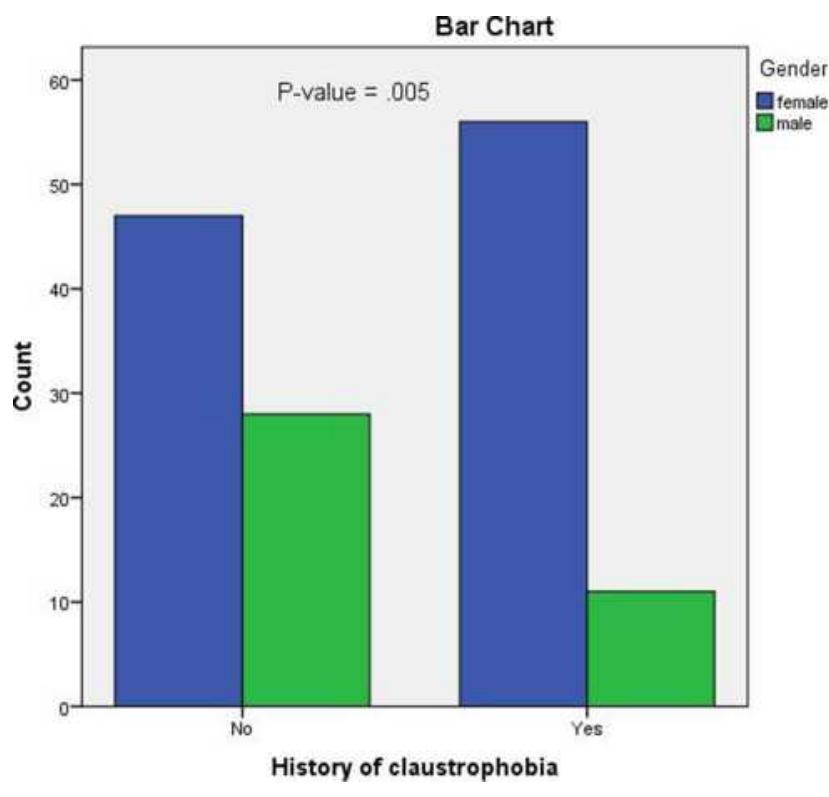

Figure I Association of claustrophobia with the gender.

\section{Attitude}

The remaining questions (12-17) assessed the attitudes of patients toward MRI safety. The patients showed positive attitudes toward recognizing the MRI safety procedures $(70.4 \%)$, screening of family members before entering the scan room $(66.2 \%)$, questioning children in the presence of parents or guardians (80.3\%), and completing the questionnaires before entering the MRI room (47.9\%). In addition, the patients responded with positive attitudes toward the technologist for explaining the MRI procedure (66.2\%), assuring and monitoring the patients at all times (71.8\%), and caring for patient during the procedure (69\%), as shown in Table 4. The mean attitude score was $0.67 \pm 0.20$. The attitude score increased in Bachelor educational level compared to Diploma and secondary schools (Table 5).

\section{Discussion}

The aim of this study was to assess levels of knowledge and attitudes toward MRI safety among patients in Saudi Arabia. The findings showed that the respondents had poor knowledge about MRIs, which might be attributed to limited background recognition for MRI safety and protection. In addition, patients were asked to do MRI examinations and were told they should be aware of the relevant safety issues.

Furthermore, this study showed that most of the patients had read or heard about the MRI safety procedures $(70.4 \%)$. In contrast, $81 \%$ responded that they were not aware of the patient preparation before the MRI 
Table 2 Knowledge of Patients Towards MRI Safety

\begin{tabular}{|c|c|}
\hline Questions & n (\%) \\
\hline $\begin{array}{l}\text { QI: Are you aware of the patient preparation } \\
\text { guidelines before MRI procedures? } \\
\text { Yes } \\
\text { No }\end{array}$ & $\begin{array}{l}27(19) \\
115(81 \%)\end{array}$ \\
\hline $\begin{array}{l}\text { Q2: Are you aware of the MRI zones? } \\
\text { Yes } \\
\text { No }\end{array}$ & $\begin{array}{l}100(70.4 \%) \\
42(29.6 \%)\end{array}$ \\
\hline $\begin{array}{l}\text { Q3: Do you know the types of radiation used } \\
\text { in MRI? } \\
\text { Yes } \\
\text { No }\end{array}$ & $\begin{array}{l}29(20.4 \%) \\
113(79.6 \%)\end{array}$ \\
\hline $\begin{array}{l}\text { Q4: Do you know the difference between } \\
\text { ionizing and non-ionizing radiation? } \\
\text { Yes } \\
\text { No }\end{array}$ & $\begin{array}{l}16(11.3 \%) \\
126(88.7 \%)\end{array}$ \\
\hline $\begin{array}{l}\text { Q5: Do you know the difference between MRI- } \\
\text { compatible and MRI-incompatible devices? } \\
\text { Yes } \\
\text { No }\end{array}$ & $\begin{array}{l}2 \mid(\mid 4.8 \%) \\
12 \mid(85.2 \%)\end{array}$ \\
\hline $\begin{array}{l}\text { Q6: Are you aware of the noise produced by } \\
\text { the MRI scanner? } \\
\text { Yes } \\
\text { No }\end{array}$ & $\begin{array}{l}76(53.5 \%) \\
66(46.5 \%)\end{array}$ \\
\hline $\begin{array}{l}\text { Q7: If there are no patients, do you think that } \\
\text { the MRI scanner is on? } \\
\text { Yes } \\
\text { No }\end{array}$ & $\begin{array}{l}44(31.0 \%) \\
98(69.0 \%)\end{array}$ \\
\hline $\begin{array}{l}\text { Q8: Do you know the adverse reactions to } \\
\text { MRI contrast agents? } \\
\text { Yes } \\
\text { No }\end{array}$ & $\begin{array}{l}34(23.9 \%) \\
108(76.1 \%)\end{array}$ \\
\hline $\begin{array}{l}\text { Q9: Are you aware of why patients undergoing } \\
\text { MRI with contrast agents must have their } \\
\text { creatinine levels (glomerular filtration rate or } \\
\text { GFR) checked? } \\
\text { Yes } \\
\text { No }\end{array}$ & $\begin{array}{l}45(31.7 \%) \\
96(67.6 \%)\end{array}$ \\
\hline $\begin{array}{l}\text { QI0: Can a pregnant woman be scanned by } \\
\text { MRI? } \\
\text { Yes } \\
\text { No }\end{array}$ & $\begin{array}{l}28(19.7 \%) \\
114(80.3 \%)\end{array}$ \\
\hline $\begin{array}{l}\text { QII: Can a pregnant woman be giving an MRI } \\
\text { contrast agent? } \\
\text { Yes } \\
\text { No }\end{array}$ & $\begin{array}{l}12(8.5 \%) \\
130(91.5 \%)\end{array}$ \\
\hline
\end{tabular}

procedures, and $88.6 \%$ did not recognize the difference between ionizing and non-ionizing radiation. Additionally, $76.1 \%$ of the participants did not recognize the adverse reactions of MRI contrast agents. Notably, 53.5\% were aware of the noise produced by the MRI scanner. The responses of the participants reflected low levels of patient knowledge regarding adverse reactions to MRI contrast agents, the difference between ionizing and non-ionizing radiation, and exposure of pregnancies to MRI. Furthermore, the patients lacked knowledge of the difference between MRI-compatible and MRI-incompatible devices, and patient preparation guidelines before MRI procedures. However, the majority had read or heard about MRI safety procedures.

Approximately $88.7 \%$ of respondents did not recognize the difference between ionizing and non-ionizing radiation, and $79.6 \%$ did know the type of radiation used in MRI. This is not surprising; in a previous study, the majority (85\%) of health care professionals in the Kingdom of Saudi Arabia and responded incorrectly that ionizing radiation is used for brain MRI in larger amounts than thorax X-rays. ${ }^{11}$ Another study reported poor knowledge about radiation exposure among radiographers, interns, and resident doctors. ${ }^{13}$

Table 3 The Total Knowledge Score Against Various SocioDemographic Data

\begin{tabular}{|l|l|l|}
\hline \multicolumn{2}{|l|}{ Variables } & $\begin{array}{l}\text { Mean Knowledge } \\
\text { Score }\end{array}$ \\
\hline Gender & Male & $0.28 \pm 0.26$ \\
& Female & $0.31 \pm 0.25$ \\
\hline Age groups & $\begin{array}{l}20-29 \text { years } \\
30-39 \text { years }\end{array}$ & $0.35 \pm 0.35$ \\
& $\begin{array}{l}40-49 \text { years } \\
\text { 50-59 years }\end{array}$ & $0.20 \pm 0.15$ \\
& $0.26 \pm 0.19$ \\
\hline Marital status & $\begin{array}{l}\text { Single } \\
\text { Married }\end{array}$ & $0.37 \pm 0.33$ \\
& $0.21 \pm 0.31$ \\
\hline Education & $\begin{array}{l}\text { Primary \& middle } \\
\text { school } \\
\text { level }\end{array}$ & $0.19 \pm 0.13$ \\
& $\begin{array}{l}\text { Higher secondary } \\
\text { school }\end{array}$ & $0.27 \pm 0.26$ \\
Diploma & Bachelor & $0.27 \pm 0.23$ \\
& $0.38 \pm 0.34$ \\
\hline Overall mean knowledge score $=0.29 \pm$ & \\
0.25 & &
\end{tabular}


Table 4 Assessment of Study-Participant Attitudes About MRI Safety

\begin{tabular}{|l|l|}
\hline Questions & $\mathbf{n}(\%)$ \\
\hline $\begin{array}{l}\text { Q I2: Have you had done an MRI scan before? } \\
\text { Yes }\end{array}$ & $100 \%$ \\
No & 0 \\
\hline $\begin{array}{l}\text { QI3: Have you read or heard about the MRI } \\
\text { safety procedures? } \\
\text { Yes }\end{array}$ & $100(70.4 \%)$ \\
No & $42(29.6 \%)$ \\
\hline $\begin{array}{l}\text { Q14: Do you think family members should be } \\
\text { screened before entering the scan room? } \\
\text { Yes }\end{array}$ & $94(66.2 \%)$ \\
No & $48(33.8 \%)$ \\
\hline $\begin{array}{l}\text { Q15: Do you think children should be } \\
\text { questioned in the presence of parents or } \\
\text { guardians? } \\
\text { Yes } \\
\text { No }\end{array}$ & \\
\hline $\begin{array}{l}\text { QI7: Did the technologist assure you that you } \\
\text { would be monitored at all times? } \\
\text { Yes } \\
\text { No }\end{array}$ & $114(80.3 \%)$ \\
\hline
\end{tabular}

Table 5 The Total Attitude Score Against Various SocioDemographic Data

\begin{tabular}{|c|c|c|}
\hline \multicolumn{2}{|l|}{ Variables } & \multirow{2}{*}{$\begin{array}{l}\begin{array}{l}\text { Mean Attitude } \\
\text { Score }\end{array} \\
0.6581 \pm 0.22 \\
0.68 \pm 0.19\end{array}$} \\
\hline Gender & $\begin{array}{l}\text { Male } \\
\text { Female }\end{array}$ & \\
\hline Age groups & $\begin{array}{l}20-29 \text { years } \\
30-39 \text { years } \\
40-49 \text { years } \\
50-59 \text { years } \\
>60 \text { years }\end{array}$ & $\begin{array}{l}0.66 \pm 0.19 \\
0.67 \pm 0.23 \\
0.66 \pm 0.21 \\
0.68 \pm 0.18 \\
0.64 \pm 0.25\end{array}$ \\
\hline $\begin{array}{l}\text { Marital } \\
\text { status }\end{array}$ & $\begin{array}{l}\text { Single } \\
\text { Married }\end{array}$ & $\begin{array}{l}0.71 \pm 0.19 \\
0.65 \pm 0.21\end{array}$ \\
\hline Education level & $\begin{array}{l}\text { Primary \& middle } \\
\text { school } \\
\text { Higher secondary } \\
\text { school } \\
\text { Diploma } \\
\text { Bachelor's degree }\end{array}$ & $\begin{array}{l}0.59 \pm 0.24 \\
0.69 \pm 0.18 \\
0.66 \pm 0.21 \\
0.71 \pm 0.18\end{array}$ \\
\hline Mean attitude $s$ & $\mathrm{re}=0.67 \pm 0.20$ & \\
\hline
\end{tabular}

Consistently, Alghamdi et al found that Saudi patient knowledge in Tabuk regarding the zoning system and type of radiation was extremely limited. ${ }^{12}$ Additionally, other studies have reported that participants believed incorrectly that MRIs and ultrasounds do not depend on ionizing radiation, whereas others stated that MRIs and ultrasounds produce ionizing radiation. ${ }^{13,14}$ The responses of the participants reflected low levels of knowledge regarding the types of and differences between ionizing and non-ionizing radiation in MRI.

The present study showed that $81 \%$ of participants stated that they did not know patient preparation guidelines for MRI procedures. This result was attributed to their insufficient knowledge about MRI investigation, about which many of them might never before have been questioned. These findings showed satisfactory attitudes in screenings of family members and caring for children before entering the MRI scan room. In addition, they revealed satisfactory attitudes toward the role of MRI technologists in caring for patients undergoing MRI procedures. Elsewhere, Alghamdi and Shrestha reported similar findings. ${ }^{12,15}$ Furthermore, it was reported that MRI technologists must keep patients safe and be capable of assessing MRI safety, patients' conditions, and compatibility of medical devices. ${ }^{15}$ This increases the need for patients to understand MRI examinations, which in most cases require preparations to improve image quality.

This study shows that knowledge of MRI safety is not affected by gender differences. Beyond this, knowledge scores increased in patients whose ages were less than 29 years compared with the other groups. Interestingly, the single patients achieved higher knowledge scores than the married ones. There has been a lack of studies concerning the awareness of MRI among different gender and age groups. In addition to this, the knowledge scores were not different in relation to the educational statuses of the participants. In contrast, Hossen et al., reported a statistically significant association between knowledge and educational status of patients. They stated that the educational statuses of the patients affected their knowledge of MRI hazards. ${ }^{16}$

Without giving sufficient knowledge to the patients, the MRI examination would not easily be able to produce highly diagnosable image quality or to prevent potential hazards. Therefore, education regarding MRI is crucial in increasing general knowledge of MRI safety. 


\section{Limitations}

This study faced several problems, as it was a single-center study without a large sample size. Thus, future studies are recommended to include a wider, more diverse population for the generalization and validation of the present results. In addition, this study included only the patients, so further studies are needed to compare patients' knowledge and attitudes with those of health care providers. For this reason, international study may be needed to examine the influence of MRI informational programs through social media, radio, and television to increase patients' knowledge of MRI safety.

\section{Conclusion}

Although the majority of patients have heard and read about MRI, heightened awareness is still lacking. Naturally, disseminating more information about MRI safety would contribute to predicting potential risks. In this note, the findings of our study highlighted the awareness of patients toward issues of MRI safety. More generally, patients should be informed about MRI exams, and useful improvements could be provided through educational interventions.

\section{Ethics Approval and Informed Consent}

Written informed consent was obtained from each participant before commencing the questionnaire responding, as requested by the Research Ethics Committee at King Khalid University (ECM\#2021-3504). "All procedures performed in this study involving human participants were in accordance with the ethical standards of the institutional and/or national research committee and with the Helsinki declaration.”

\section{Acknowledgments}

We would like to thank all the patients in Asir Central Hospital and Armed Forces for their time and willingness to participate in the study. We also appreciate the role of staff and clinicians and MRI Department for their great help.

\section{Author Contributions}

All authors made substantial contributions to conception and design, acquisition of data, or analysis and interpretation of data; took part in drafting the article or revising it critically for important intellectual content; agreed to submit to the current journal; gave final approval for the version to be published; and agree to be accountable for all aspects of the work.

\section{Funding}

The authors extend their appreciation for funds provided by the deanship of Scientific Research at King Khalid University through grant number GRP-232-40.

\section{Disclosure}

The authors declare no conflicts of interest.

\section{References}

1. Tsai LL, Grant AK, Mortele KJ, Kung JW, Smith MP. A practical guide to MR imaging safety: what radiologists need to know. RadioGraphics. 2015;35(6):1722-1737. doi:10.1148/rg.2015150108

2. Lau LU, Thoeni RF. Uterine lipoma: advantage of MRI over ultrasound. $B r \quad J$ Radiol. 2005;78(925):72-74. doi:10.1259/bjr/ 61054799

3. Advanced imaging and contrast concepts Magnetic resonance imaging | NMR MR MRI | essentials, introduction, basic principles, facts, history | the primer of EMRF/TRTF. Available from: https://www. magnetic-resonance.org/ch/1103.html. Accessed February 4, 2021.

4. Stecco A, Saponaro A, Carriero A. Patient safety issues in magnetic resonance imaging: state of the art. Radiol Med. 2007;112 (4):491-508. doi:10.1007/s11547-007-0154-4

5. Kanal E, Borgstede JP, Barkovich AJ, et al. American college of radiology white paper on MR Safety. Am J Roentgenol. 2002;178 (6):1335-1347. doi:10.2214/ajr.178.6.1781335.

6. Kanal E, Barkovich AJ, Bell C, Borgstede JP, Bradley WG Jr, Froelich JW. Expert PANEL on MR safety, ACR guidance document on MR safe practices: 2013. J Magn Reson Imaging. 2013;37 (3):501-530. doi:10.1002/jmri.24011

7. Shellock FG. Radiofrequency energy-induced heating during MR procedures: a review. J Magn Reson Imaging. 2000;12(1):30-36. doi:10.1002/1522-2586(200007)12:1<30::AID-JMRI4>3.0.CO;2-S

8. Ham CL, Engels JM, Van de Wiel GT, Machielsen A. Peripheral nerve stimulation during MRI: effects of high gradient amplitudes and switching rates J Magn Reson Imaging. 1997;7(5):933-937.

9. Murphy KJ, Brunberg JA. Adult claustrophobia, anxiety and sedation in MRI. Magn Reson Imaging. 1997;15(1):51-54. doi:10.1016/ s0730-725x(96)00351-7

10. McJury M, Shellock FG Auditory noise associated with MR procedures: a review. J Magn Reson Imaging. 2000;12(1):37-45.

11. Alghamdi A, Alsharari Z, Almatari M, et al. Radiation risk awareness among health care profes sionals: an online survey. J Radiol Nurs. 2019;39:132-138. doi:10.1016/j.jradnu.2019.11.004

12. Alghamdi A, Alqahtani A, Alghamdi AJ, et al. Patient perception and attitudes toward magnetic resonance imaging safety. AMJ. 2021;14 (1):34-42.

13. Günalp $\mathrm{M}$, Gülünay $\mathrm{B}$, Polat $\mathrm{O}$, et al. Ionising radiation awareness among resident doctors, interns, and radiographers in a university hospital emergency department. Radiol Med. 2014;119:440-447. doi:10.1007/s11547-013-0374-8.

14. Heyer CM, Hansmann J, Peters SA, Lemburg SP. Paediatrician awareness of radiation dose and inherent risks in chest imaging studiesda questionnaire study. Eur J Radiol. 2010;76:288-293. doi:10.1016/j.ejrad.2009.06.014.

15. Shrestha S, Khadka B. Assessment of patients' knowledge, perception and safety regarding MRI scan. J Manmohan Meml Inst Health Sci. 2020;6(1):3-19. doi:10.3126/jmmihs.v6i1.30532.

16. Hossen M, Rana S, Parvin T, Muraduzzaman SM, Jalali MA. Evaluation of awareness and attitude of Radiological technologists towards MRI safety in Dhaka city of Bangladesh. International journal of pure medical research. 2020;5(5):16-18. 


\section{Publish your work in this journal}

Patient Preference and Adherence is an international, peer-reviewed, open access journal that focusing on the growing importance of patient preference and adherence throughout the therapeutic continuum. Patient satisfaction, acceptability, quality of life, compliance, persistence and their role in developing new therapeutic modalities and compounds to optimize clinical outcomes for existing disease

states are major areas of interest for the journal. This journal has been accepted for indexing on PubMed Central. The manuscript management system is completely online and includes a very quick and fair peer-review system, which is all easy to use. Visit http:// www.dovepress.com/testimonials.php to read real quotes from published authors. 